\title{
Habitat Requirements of Breeding Black-Backed Woodpeckers (Picoides arcticus) in Managed, Unburned Boreal Forest
}

\section{Besoins en termes d'habitat chez le Pic à dos noir (Picoides arcticus) nichant en forêt boréale non brûlée et sous aménagement}

\author{
$\underline{\text { Junior A. Tremblay }}^{1}, \underline{\text { Jacques Ibarzabal }}^{2}, \underline{\text { Christian Dussault }}^{1}$, and $\underline{\text { Jean-Pierre L. Savard }}^{3}$
}

\begin{abstract}
We investigated home-range characteristics and habitat selection by Black-backed Woodpeckers (Picoides arcticus) in an unburned, boreal forest landscape managed by mosaic harvesting in Quebec, Canada. Habitat selection by this species was specifically examined to determine home-range establishment and foraging activities. We hypothesized that Black-backed Woodpeckers would respond to harvesting by adjusting their home-range size as a function of the amount of dead wood available. Twenty-two birds were tracked using radiotelemetry, and reliable estimates of home-range size were obtained for seven breeding individuals (six males and one female). The average home-range size was $151.5 \pm 18.8$ ha (range: $100.4-256.4$ ha). Our results indicate that this species establishes home ranges in areas where both open and forested habitats are available. However, during foraging activities, individuals preferentially selected areas dominated by old coniferous stands. The study also showed that the spatial distribution of preferred foraging habitat patches influenced space use, with home-range area increasing with the median distance between old coniferous habitat patches available within the landscape. Finally, these data show that Black-backed Woodpeckers may successfully breed in an unburned forest with at least $35 \mathrm{~m}^{3} \bullet \mathrm{ha}^{-1}$ of dead wood, of which $42 \%\left(15 \mathrm{~m}^{3} \bullet \mathrm{ha}^{-1}\right)$ is represented by dead wood at the early decay stage.

RÉSUMÉ. Nous avons étudié les caractéristiques du domaine vital et la sélection de l'habitat chez le Pic à dos noir (Picoides arcticus) en forêt boréale non brûlée et aménagée par coupes en mosaïque, au Québec (Canada). La sélection de l'habitat a été tout particulièrement examinée afin de déterminer le domaine vital et les activités liées à l'alimentation chez cette espèce. Nous avons émis l'hypothèse selon laquelle le Pic à dos noir réagirait à la récolte de bois en modifiant la taille de son domaine vital selon la quantité de bois mort accessible. Vingt-deux oiseaux ont été suivis à l'aide de la télémétrie et des estimations fiables de la taille du domaine vital ont été obtenues pour sept individus nicheurs (six mâles et une femelle). La taille moyenne du domaine vital a été évaluée à 151,5 $\pm 18,8$ ha (étendue : 100,4-256,4 ha). Nos résultats indiquent que cette espèce établit son domaine vital là où des milieux ouverts et des milieux forestiers sont accessibles. Toutefois, au moment de s'alimenter, les individus sélectionnent préférablement les endroits où dominent les peuplements de vieux conifères. Les travaux ont également montré que la répartition spatiale des îlots d'habitat préférés pour l'alimentation du pic influence l'utilisation de l'espace : la taille du domaine vital augmente en fonction de la distance médiane entre les îlots de vieux conifères accessibles dans le paysage. Enfin, les résultats indiquent que le Pic à dos noir peut nicher avec succès en forêt non brûlée s'il y a un volume de bois mort d'au moins $35 \mathrm{~m}^{3} \bullet \mathrm{ha}^{-1}$, dont $42 \%\left(15 \mathrm{~m}^{3} \bullet \mathrm{ha}^{-1}\right)$ est en début de décomposition.
\end{abstract}

Key Words: cavity-associated species management; dead wood; foraging ecology; habitat use; radiotelemetry

${ }^{1}$ Ministère des Ressources naturelles et de la Faune du Québec, Direction de l'expertise sur la faune et ses habitats, ${ }^{2}$ Université du Québec à

Chicoutimi, ${ }^{3}$ Environment Canada, Canadian Wildlife Service

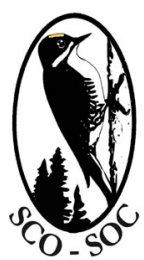

Sponsored by the Society of Canadian Ornithologists and Bird Studies Canada Parrainée par la Société des ornithologistes du Canada et Études d'oiseaux Canada

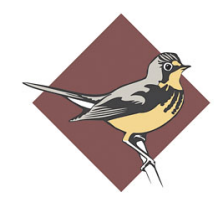
Bird STUDiES CANADA 


\section{INTRODUCTION}

The boreal forest is a dynamic ecosystem where natural and anthropogenic disturbances shape the landscape (Bergeron et al. 2001, 2002). Forest fires are the main source of natural disturbance in this biome, with millions of hectares of forest being consumed annually in Canada (Girardin et al. 2008). However, timber harvesting has recently become the main perturbation in this ecosystem (McRae et al. 2001). In harvested landscapes, a proportion of old-growth forest is being replaced by younger stands (Drapeau et al. 2005), which are characterized by a lower volume of dead wood (Darveau and Desrochers 2001). Furthermore, the distribution of harvested areas in the landscape alters the abundance and distribution of dead wood and is likely to influence movement patterns and space use by primary cavity-nesting species such as woodpeckers (Picoides spp.) (Pasinelli 2000, Pechacek 2004), which rely on decaying wood for foraging and nesting (Backhouse 2005). Significant changes in the abundance of primary cavity nesters could have a knock-on effect on various species of birds and mammals that are secondary users of tree cavities (Martin and Eadie 1999, Martin et al. 2004). Examples of species that regularly use woodpecker cavities in the eastern Canadian boreal forest include the Eastern Bluebird (Sialia sialis), Tree Swallow (Tachycineta bicolor), and red squirrel (Tamiasciurus hudsonicus).

There are relatively few primary cavity nesters in the conifer-dominated boreal forest of Canada, the most abundant being the American Three-toed Woodpecker (Picoides dorsalis) and Black-backed Woodpecker (Picoides arcticus). These species depend on snags at the early decay stage for foraging and nesting (Raphael and White 1984, Goggans et al. 1989, Villard and Beninger 1993, Villard 1994, Imbeau and Desrochers 2002b). American and European Three-toed Woodpeckers (Picoides tridactylus) are associated with old-growth spruce (Picea spp.) stands (Virkkala 1987, Imbeau et al. 1999), but the importance of mature and overmature forests in the ecology of Black-backed Woodpeckers is still unclear (Raphael and White 1984). Although many authors have associated Black-backed Woodpeckers with recent post-fire stands (Hutto 1995, Murphy and Lehnhausen 1998, Powell 2000), this may reflect the fact that most of the recent studies on this species have been conducted in these habitats (Murphy and Lehnhausen 1998, Nappi et al. 2003, Dudley and
Saab 2007, Koivula and Schmiegelow 2007, Saab et al. 2007, Nappi and Drapeau 2009), and little information is available from mature and overmature forest stands (Goggans et al. 1989). Goggans et al. (1989), in one of the few studies dealing with the ecology of American Three-toed and Black-backed Woodpeckers in unburned forests, found that Black-backed Woodpeckers in lodgepole pine (Pinus contorta) forests in Oregon positively selected mature and overmature stands, and avoided younger stands and logged areas. As a result of this study, the authors recommended that the Black-backed Woodpecker, rather than the American Three-toed Woodpecker, be used as an indicator species for mature and old-growth lodgepole pine stands (Goggans et al. 1989). Studies on sympatric American Three-toed and Blackbacked Woodpeckers in unburned forest stands have shown that Black-backed Woodpeckers use larger and less decayed trees than American Threetoed Woodpeckers (Bull et al. 1986, Villard 1994). Black-backed Woodpeckers appear to be oldgrowth dependent and more abundant than American Three-toed Woodpeckers in the eastern boreal forest (Thompson et al. 1999, Setterington et al. 2000) and could, therefore, serve as an indicator species in this forest type. The Black-backed Woodpecker occurs almost exclusively in $\geq 80$ year-old forest stands and appears to be sensitive to the dead-wood removal typical of modern forestry (Thompson et al. 1999). Information about habitat and space use by, and the resilience of, Blackbacked Woodpeckers in managed boreal forests is lacking, but is of primary importance in assessing the impact of large-scale forestry on this species, and on secondary cavity users in the eastern boreal forest of Canada. This is especially true given that forestry is now the dominant disturbance factor in the boreal forest and occurs in most parts of Blackbacked Woodpecker's distribution range.

We investigated home-range characteristics and habitat selection of Black-backed Woodpeckers in unburned forest stands in order to identify quantitative targets for habitat management. Because of the Black-backed Woodpecker's association with recently decayed dead wood for nesting and foraging (Raphael and White 1984, Bull et al. 1986, Goggans et al. 1989, Murphy and Lehnhausen 1998), we hypothesized that its occurrence would be negatively influenced by timber harvesting. More specifically, we predicted that: (1) Black-backed Woodpeckers would establish their home range in old coniferous stands 
and avoid cut stands, (2) they would select old coniferous stands for foraging, and (3) their homerange size would be related to the amount of dead wood available, with home ranges shrinking as dead-wood volume increases. Our results provide information that should favor the conservation of this saproxylic species in landscapes shaped by modern forestry practices.

\section{METHODS}

\section{Study Area}

The study area, within the black sprucefeathermoss forest of the Canadian boreal forest ecological domain (Saucier et al. 1998), covered $650 \mathrm{~km}^{2}$ and was located $200 \mathrm{~km}$ northwest of Lac Saint-Jean, Quebec, Canada (50 $34^{\circ} \mathrm{N}, 72^{\circ} 10^{\prime} \mathrm{W}$ : 200-650 m a.s.l.: Fig. 1). Forest stands were composed mainly of black spruce (Picea mariana) or black spruce mixed with jack pine (Pinus banksiana), balsam fir (Abies balsamea), white birch (Betula papyrifera), and aspen (Populus tremuloides), with a scattering of tamarack (Larix laricina). Forest fires were the major natural disturbances, followed by spruce budworm (Choristoneura fumiferana) outbreaks. Commercial timber harvesting and forest management at this latitude began in the last decade and the study area was logged using a mosaic harvesting regime, which resulted in logged and residual forested blocks interspersed over the landscape (Fig. 2). Even-aged stand management (cutting with regeneration and soil protection, CRSP) techniques were practiced in the southern part of the study area and uneven-aged stand management (cutting with little merchantable tree protection, CLMTP) in the northern part.

\section{Trapping and Radio Tracking}

Black-backed Woodpeckers were located from mid-May to mid-June in 2005 and 2006 using roadside surveys with playbacks of conspecific calls and drumming (Ibarzabal and Desmeules 2006). Playback stations were systematically established at $1-\mathrm{km}$ intervals along major roads, which allowed habitat types to be sampled in proportion to their availability within the study area. Burned areas and a 2-km buffer zone around them were not sampled. Woodpeckers were captured using mist nets, and individuals showing evidence of breeding (i.e., presence of a brood patch) were fitted with a tailmounted radiotransmitter (2.3 g; Model PD-2, Holohil Systems Ltd, Carp, Ontario) attached at the base of the two central rectrices. Transmitter batteries lasted about 8-10 weeks and the birds were followed from the hatching period up until the chicks fledged (i.e., 4-5 weeks). An individual that fledged at least one young was defined as a breeder.

Birds were located using the homing method (Mech 1983) with TRX-2000S radio receivers (Wildlife Materials, Murphysboro, Illinois) and threeelement Yagi antennas. Individual woodpeckers were tracked at different times of the day to prevent bias related to cyclic behavior. For logistical reasons, we tried to alternate half days of data collection between woodpeckers wearing transmitters to collect data in both periods of the day (for instance, a woodpecker tracked before noon was tracked the next time after noon). Individuals were approached to within $10 \mathrm{~m}$ to establish visual or aural contact without disturbing them or, alternatively, to estimate location $( \pm 5 \mathrm{~m})$. The latter was recorded using hand-held GPS units (GPS Legend, Garmin Corp., Olathe, Kansas; $\pm 10 \mathrm{~m}$ ) and the bird's behavior was classified as foraging or not foraging. When the bird flew, the observer tried to follow it to record further location points. The birds continued their normal activities as long as observers kept a >3-m distance. We considered consecutive location data points to be spatially independent if $>100 \mathrm{~m}$ apart (Pechacek and OleireOltmanns 2004). The breeding cavity was considered as a single independent location, and to avoid undue influence on home-range size, no other location data points were taken within a 100-m radius (Pechacek 2004).

\section{Assessment of Home-Range Size and Habitat Selection}

Individual home ranges were calculated with Range VI software (Kenward et al. 2003), using all independent locations (foraging or not) and the minimum convex polygon method (100\% MCP; Hayne 1949). Although the MCP method can include unused areas and has been criticized (White and Garrott 1990, Powell 2000, Kenward 2001), it is an appropriate method to assess the composition of home ranges in terms of habitat type (i.e., habitat availability at a given home-range scale). In contrast, the Kernel estimator performs poorly when there are relatively few location points available 
Fig. 1. Habitat configuration, observed home ranges, and study area boundaries located $200 \mathrm{~km}$ northwest of Lac Saint-Jean, Quebec, Canada. The study-area boundaries were determined by creating a 4-km buffer zone (1 km playback carrying distance plus $3 \mathrm{~km}$ potential bird displacement) on both sides of the roads traveled during capture operations (different in 2005 and 2006).

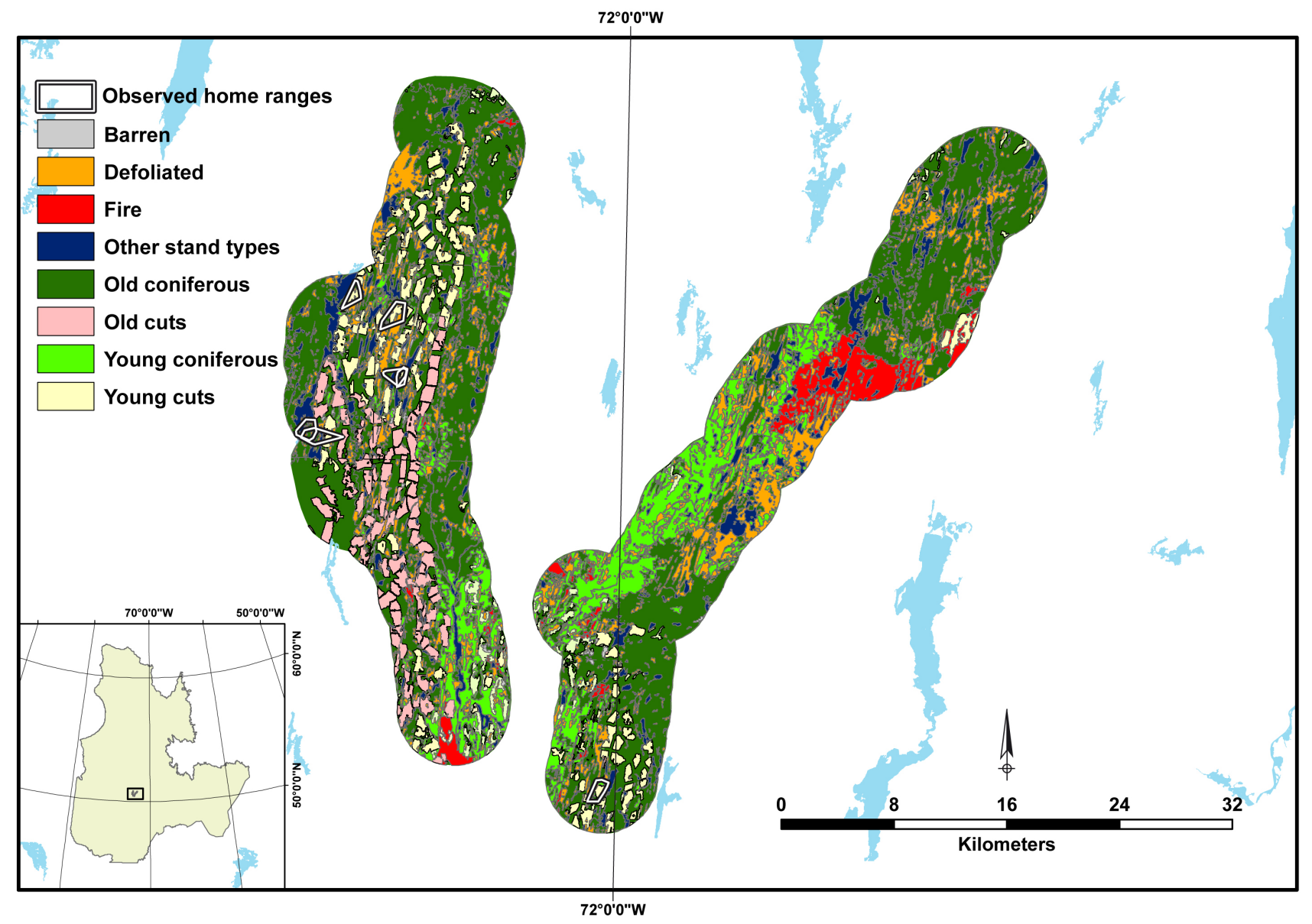

(Worton 1989), tending to break the home range into several parts, which does not allow a suitable description of the habitat matrix at the landscape scale. Furthermore, for management purposes, we feel that the MCP provides a suitable estimate of the area of boreal forest required by an individual Black-backed Woodpecker. The MCP size was estimated for individuals for which the relationship between home-range size and number of locations reached an asymptote $(n=8$; seven breeders and one non-breeder) (Seaman et al. 1999). For habitatselection analyses, only breeding individuals were considered [landscape ( $n=$ eight home ranges; the seven breeders indicated above plus another breeder for which the relationship between home-range size and number of locations did not reach an asymptote) and home-range scales $(n=128$ foraging locations)]. The study-area boundaries were determined by creating a 4-km buffer zone $(1 \mathrm{~km}$ playback carrying distance plus $3 \mathrm{~km}$ potential bird displacement) on both sides of the roads traveled during capture operations (Fig. 1). This was based on previous observations of Black-backed Woodpeckers up to $3 \mathrm{~km}$ from their roadside capture location (J.A.T. and J.I., unpublished data). The study area differed slightly between 2005 and 2006, and habitat maps were updated to incorporate disturbances (i.e., fires and logging; data provided 
Fig. 2. Example of interspersed landscape of logged and residual forested blocks after the first pass of the mosaic harvesting regime in the study area.

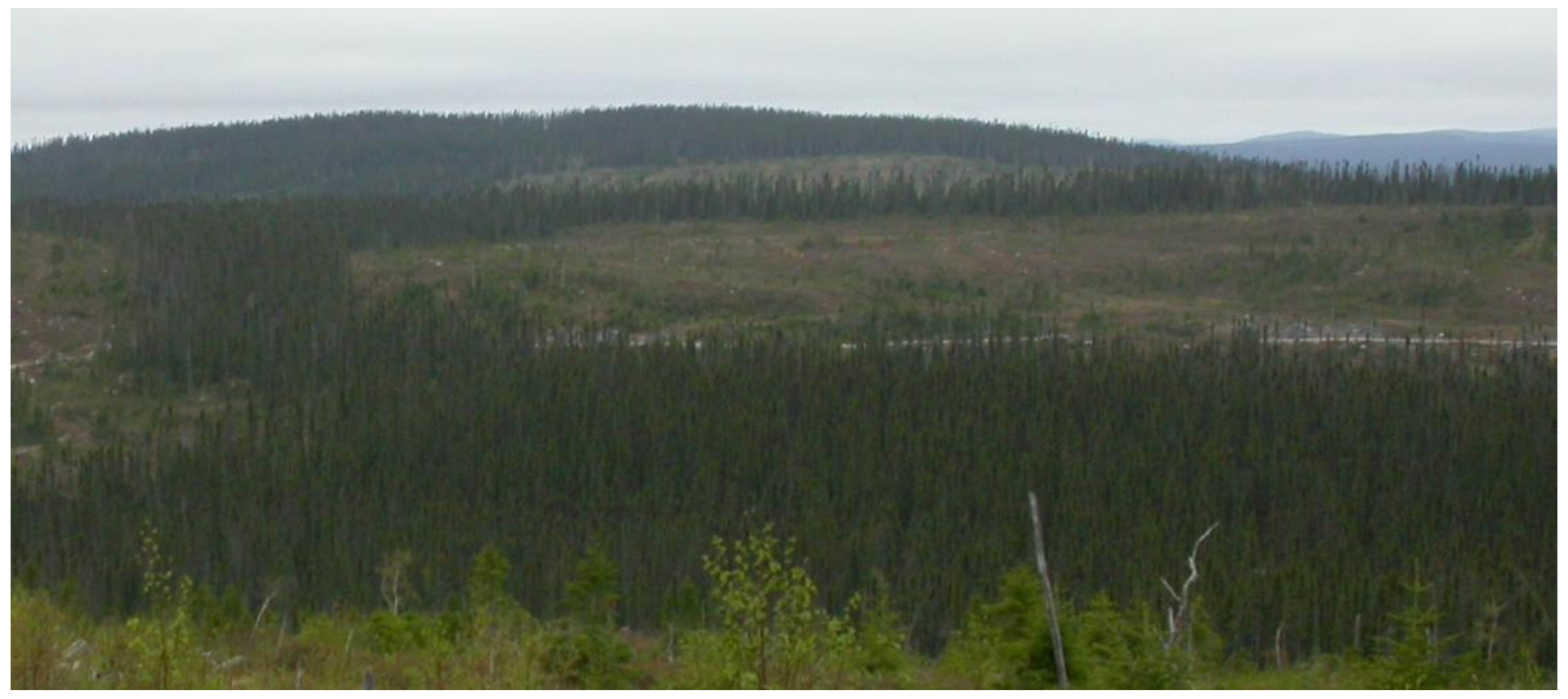

by AbitibiBowater Inc.) that occurred between the two consecutive field seasons.

Habitat selection of Black-backed Woodpeckers was examined at two spatial scales to assess the possibility of hierarchical selection. At the larger scale, hereafter referred to as the landscape scale, habitat composition within home ranges was compared with that of random home ranges (second-order selection; Johnson 1980). At the smaller scale (home-range scale), habitat at telemetry locations used during their foraging activities was compared with habitat found at random locations within individual home ranges (third-order selection; Johnson 1980).

To assess habitat selection at the landscape scale, habitat composition (proportion of habitat types) within breeding woodpecker home ranges was compared with that of a control home range per individual (eight observed and eight random home ranges). The latter were randomly positioned within the study area (translation and rotation). To determine the composition of observed and random home ranges, these were overlaid onto digitized habitat layers. ArcView Geoprocessing Wizard (Environmental Systems Research Institute (ESRI)
1996) was used to clip habitat types within homerange boundaries and calculate their proportions. At the home-range scale, habitat use was assessed using only locations when individuals were classified as foraging, and availability was assessed by drawing one random location per observed location within each Black-backed Woodpecker home range. This provided a total of 128 observed and 128 random locations. Habitat types were established using 1:20 000 forest maps published by the Quebec Ministry of Natural Resources in 1992. These maps provide accurate information when conducting a simple classification based on cover type and stand age (Potvin et al. 1999, Dussault et al. 2001). Predominant habitat types in the study area were barren lands, defoliated stands (windthrows and spruce budworm outbreak stands), young ( $<90$ years old) and old ( $>90$ years old) coniferous stands, and recent $(<5$ years old) and old ( $>5$ years old) cuts. Fragstats 3.3.5 (McGarigal et al. 2002) was used to calculate the median distance between each patch and the nearest neighboring patch of the same habitat type, based on the centerto-center distance (McGarigal et al. 2002), to characterize the distribution of habitat patches within each home range. 


\section{Sampling Dead Wood}

Snag abundance was estimated on circular plots (0.04 ha) randomly distributed within the different home ranges. One plot was sampled for every 20 ha of home-range area and habitat types within woodpecker home ranges were sampled in proportion to their availability. The number of fallen logs were counted along three 20-m transects starting at $1 \mathrm{~m}$ from the plot center (Böhl and Brändli 2007). For snags and $\operatorname{logs}_{s}$ with a diameter at breast height (dbh) $>5 \mathrm{~cm}$, species, decay class, snag dbh and height, and log length and dbh at the line/log intersection point were recorded (Table 1). For snags that were severely leaning, an angle of $45^{\circ}$ was used as the cutoff between a snag and a fallen $\log$ (Harmon and Sexton 1996). Log volume was calculated for each habitat type following Böhl and Brändli (2007). Even if Black-backed Woodpeckers showed a preference for snags, we noted that they were feeding on logs $20 \%$ of the time in the same study area (Tremblay et al., unpublished data). For this reason, we combined the volume of snags and logs in two categories: "all dead wood" and "dead wood at the early decay stage." The latter included classes 1 and 2 for snags and logs (Table 1).

\section{Statistical Analysis}

Habitat selection was assessed at the landscape and home-range scales using resource selection functions (RSF). We used mixed-effects logistic regressions (PROC GLIMMIX; SAS Institute 2008) that allowed us to consider the nonindependence between repeated measurements on the same individuals (i.e., observed and random data). We used individual ID as random factor and the proportion of the following habitat types within each woodpecker home range as variables to model habitat selection at the landscape scale: barren lands, young ( $<90$ years old) and old ( $>90$ years old) coniferous stands, recent $(<5$ years old) and old $(>5$ years old) cuts. At the home-range scale, we also used woodpecker ID as random factor but instead used the proportion of telemetry locations falling within the abovementioned habitat types as independent variables. Threshold-independent receiver operating characteristic curves (ROC, calculated using Glimmroc macro developed by Liu and $\mathrm{Wu} 2003$ ) were used to assess regression model performance (Zweig and Campbell 1993). The ROC curve depicts sensitivity (proportion of true positives correctly predicted) and specificity (proportion of true negatives correctly predicted) pairs for the entire threshold range (Manel et al. 2001). It is generated by plotting sensitivity over one specificity. The area under this curve (AUC) provides an accurate measure of model performance. An AUC of 0.5 indicates that a model predicts no better than by chance, whereas an AUC of 1.0 indicates the model can perfectly distinguish between observed and random sites. Linear regression was used to examine the influence of dead wood on home-range size.

Statistical analyses were conducted using SAS version 9.1 (SAS Institute 2008) and effects with $p$ $\leq 0.05$ were considered to be significant. Unless otherwise stated, the data shown are means \pm 1 SE.

\section{RESULTS}

During the 2 years of the study, 38 Black-backed Woodpeckers were captured in unburned forests. Of these, 22 were fitted with radio transmitters. Signals were obtained from 17 birds and of those, four lost their radio transmitters. A sufficient number of locations were obtained to assess the home-range size of eight woodpeckers (i.e., the relationship between home-range size and number of locations reached an asymptote): seven breeders and one unsuccessful female (clutch failed to hatch). The average number of independent locations was 36 per bird (range: $28-50 ; n=7$ ). Mean home-range size was $151.5 \pm 18.8$ ha (range: $100.4-256.4$ ha; $n$ $=7$ ) for successfully breeding woodpeckers. The home-range size of the bird that made an unsuccessful nesting attempt was 385.8 ha.

Old coniferous stands and recent cuts were the most abundant habitat types in the home ranges of breeding Black-backed Woodpeckers, each accounting for nearly a third of the area (Fig. 3). In contrast, defoliated stands and old cuts were almost absent (Fig. 3). At the landscape scale, woodpeckers non-significantly selected areas with a high proportion of recent cuts to establish their home range (Table 2).

Black-backed Woodpeckers foraged mostly in old coniferous stands and were never observed foraging in defoliated or in old cut stands (Fig. 4) and they also avoided recent cuts at the home-range scale (Table 2). 
Table 1. Decay classes (1-5) for fallen logs and snags (modified from Tyrrell and Crow 1994; Bergeron et al. 1997).

\begin{tabular}{|c|c|c|c|c|c|c|}
\hline \multirow[t]{2}{*}{ Decay class } & \multicolumn{3}{|c|}{ Fallen log characteristics } & \multicolumn{3}{|c|}{ Snag characteristics } \\
\hline & Leaves & Wood & Shape and form & Leaves & Bark & Top and height \\
\hline 1. Recent & present & solid & round & present & present & intact \\
\hline 2. Solid & absent & solid & round & absent & $>50 \%$ & intact \\
\hline 3. Solid decayed & absent & solid/punky & round/oval & absent & $<50 \%$ & intact \\
\hline 4. Decayed & absent & punky & $\begin{array}{l}\text { oval, form } \\
\text { retained }\end{array}$ & absent & absent & $\begin{array}{l}\text { broken, height } \\
>50 \%\end{array}$ \\
\hline 5. Very Decayed & absent & punky & \pm oval, collapsed & absent & absent & $<2 \mathrm{~m}$ \\
\hline
\end{tabular}

Habitat types differed greatly in terms of total volume of dead wood and volume of dead wood at the early decay stage (Table 3). Globally, old coniferous stands supported the highest volume of dead wood, snags, and fallen logs, whereas barren lands exhibited the lowest total dead-wood volume and recent cuts exhibited the lowest amount of dead wood at the early decay stage. The amount of dead wood was highly variable between sample sites in young and in old coniferous stands (Table 3 ).

No relationship was found between total dead-wood volume $\left(\beta_{\mathrm{i}}=-0.0302 ; t\right.$-value $=-0.41 ; \mathrm{r}^{2}=0.0323$; $p=0.6999)$ or that at the early decay stage $\left(\beta_{\mathrm{j}}=\right.$ $0.0093 ; t$-value $\left.=0.28 ; \mathrm{r}^{2}=0.0157 ; p=0.7890\right)$ and Black-backed Woodpeckers home-range size $(n=$ 7). However, the median distance between the nearest old coniferous habitat patches influenced home-range size $\left(\beta_{\mathrm{j}}=0.2325 ; t\right.$-value $=2.23 ; \mathrm{r}^{2}=$ $0.4987 ; p=0.0761$ ). Thus, home-range size tended to increase with distance between old coniferous habitat patches.

The home ranges of breeding woodpeckers contained more than $35 \mathrm{~m}^{3} \cdot \mathrm{ha}^{-1}$ of decayed dead wood and the mean dead-wood volume per home range was $42.4 \pm 3.2 \mathrm{~m}^{3} \bullet \mathrm{ha}^{-1}(n=7$; Table 4$)$. Dead wood at the early decay stage was abundant in home ranges, with a mean volume of $18 \pm 1.4 \mathrm{~m}^{3} \cdot \mathrm{ha}^{-1}$ (Table 4). Snags represented approximately half of the volume of dead wood, the mean snag volume per home range was $19.8 \pm 2.7 \mathrm{~m}^{3} \bullet \mathrm{ha}^{-1}$, of which $9.4 \pm 1.4 \mathrm{~m}^{3} \bullet \mathrm{ha}^{-1}$ were snags at the early decay stage (Table 4).

\section{DISCUSSION}

This study provides new information on Blackbacked Woodpeckers, which has landscape management implications for this little-studied keystone species of the boreal forest. Although the results obtained were for a relatively small sample size (eight home ranges of breeding individuals), it allowed habitat selection to be determined for breeding birds in unburned tracts of forest. This species established home ranges in areas with both open and forested habitats, but during foraging activities, patches of old coniferous forests were preferentially selected. No relationship was found between the amount of dead wood available and home-range size for successfully breeding Blackbacked Woodpeckers in unburned boreal forest stands. However, the spatial distribution of the preferred foraging habitat (old conifer patches) seemed to influence the home-range size.

\section{Home-Range Size}

To the best of our knowledge, this study is the first to document foraging behavior and habitat use of the Black-backed Woodpecker in unburned, nonbeetle-killed forests of North America. The home ranges described by Goggans et al. (1989) in beetlekilled lodgepole pine stands within commercial mature to overmature forests in Oregon, were similar to those described in the present study $(n=$ 7) but slightly larger in size (mean $=174.7 \mathrm{ha}$, range $=72-328$ ha, $n=3$ ). Most locations recorded by 
Fig. 3. Habitat composition (mean \pm SE) of Black-backed Woodpecker home ranges (gray bars; $n=8$ ) and randomly distributed home ranges (empty bars; $n=8$ ). Habitat types were defined as barren, stands defoliated by windthrows and spruce budworm outbreak, young ( $<90$ years) and old ( $>90$ years) coniferous stands, and young ( $<5$ years $)$ and old ( $>5$ years $)$ cuts.

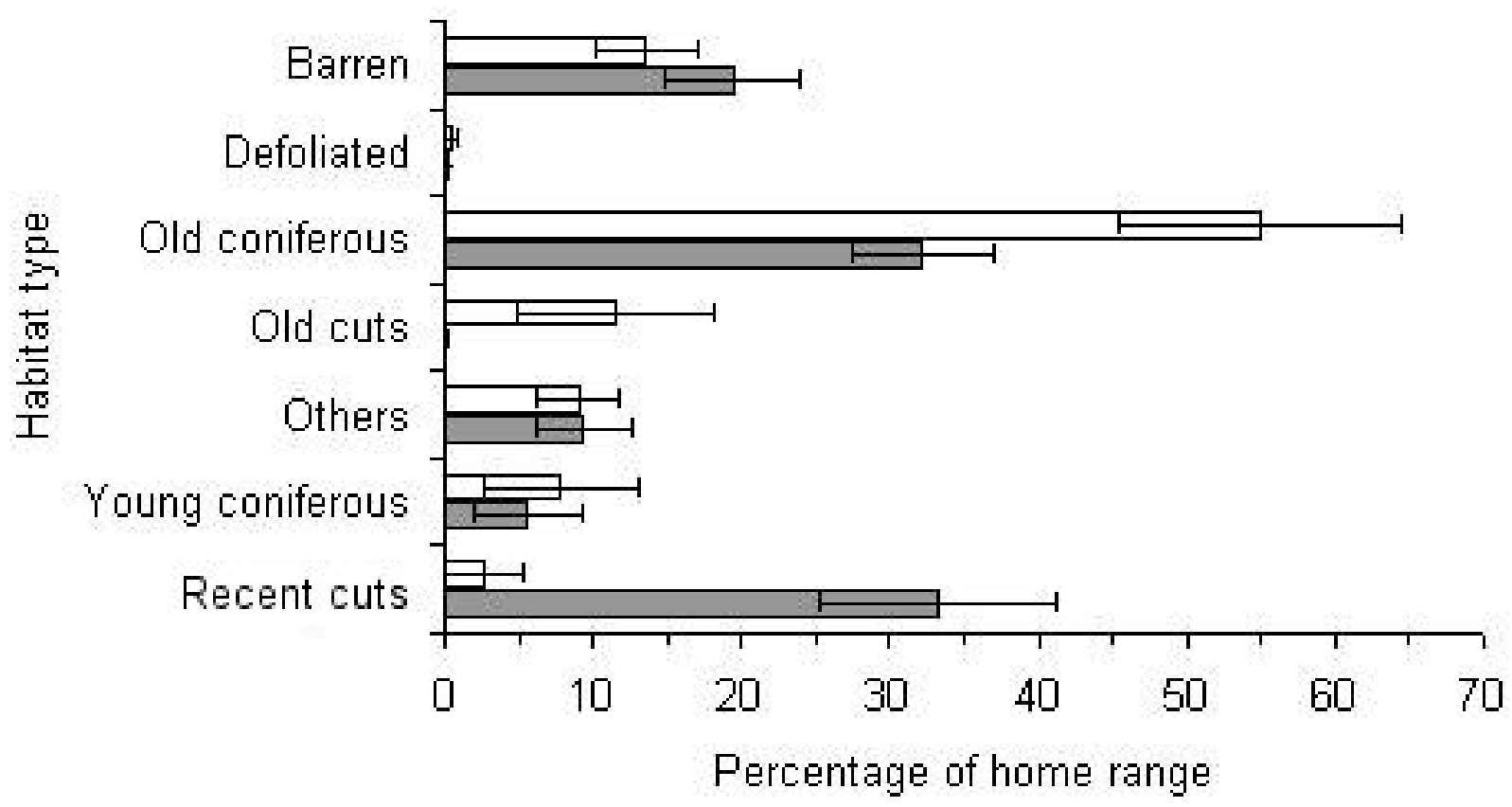

Goggans et al. (1989) and subsequently used to estimate home-range size were taken after the young had fledged or after failed nesting attempts. In contrast, location points in this study were recorded between hatching and fledging. A recent study on European Three-toed Woodpeckers showed that this species increases home-range size after the chicks fledge (Pechacek 2004). Because we expect Black-backed Woodpeckers to behave in a similar manner, the mean home-range area of 151.5 ha estimated in our study should be considered as the minimum area required by this species during the breeding season, and probably on an annual basis in unburned tracts of eastern boreal forest. This assumption is further supported by the larger home range (385.8 ha) of the single non-breeding individual that was followed in the study.

\section{Habitat Selection}

At the landscape scale, Black-backed Woodpeckers tended to establish their home ranges in areas with a high proportion of recent cuts $(n=8 ;$ Fig. 3$)$. This was unexpected, as many authors have reported Black-backed Woodpecker nests to be associated with areas of high tree or snag density (Raphael and White 1984, Saab and Dudley 1998, Saab et al. 2002). However, 51\% of the Black-backed Woodpecker nests $(n=35)$ located by Goggans et al. (1989) were in logged stands. This supports the findings of the present study, where they were often observed nesting in recent cuts (Tremblay et al., unpublished data). Most of the latter originated from CLMTP that left some large snags suitable for nesting. The study area was characterized by an interspersion of large residual forest blocks, half of which were composed of old coniferous habitat and harvested areas. Given the dominance of old conifer stands in the landscape, the major limiting factor 
Table 2. Logistic regression models predicting Black-backed Woodpecker occurrence $(n=8)$ according to habitat type at the landscape and home-range scales (AUC = area under the ROC curve, an index of model fit).

\begin{tabular}{lllll}
\hline \hline$\beta_{\mathrm{j}}$ & Standard Error & Odds ratio & Odds ratio CI & AUC \\
\hline
\end{tabular}

Landscape scale

Young cuts

0.1069

0.0562

1.113

$0.974-1.271$

0.828

Home-range scale

\begin{tabular}{llllll} 
Old coniferous & 0.8711 & 0.2109 & 2.390 & $1.343-4.252$ & 0.717 \\
Young cuts & -2.2328 & 0.5658 & 0.107 & $0.035-0.327$ & \\
\hline
\end{tabular}

influencing Black-backed Woodpecker homerange establishment may have been the availability of suitable open nesting habitat, rather than the availability of foraging habitat. This factor might explain the observed tendency toward selecting recent cuts within the landscape for home-range establishment.

At the home-range scale, Black-backed Woodpeckers foraged in old coniferous stands and avoided recent cuts. This species is known to preferentially forage on recently decayed coniferous species (Raphael and White 1984, Goggans et al. 1989, Murphy and Lenhausen 1998, Nappi et al. 2003). We found that old coniferous stands offered about $30 \mathrm{~m}^{3} \cdot \mathrm{ha}^{-1}$ of dead wood at the early decay stage. By contrast, this figure dropped to $<9 \mathrm{~m}^{3} \bullet \mathrm{ha}^{-1}$ in recent cuts. In our study area, Black-backed Woodpeckers were regularly observed to nest in recent cuts and travel to nearby old coniferous patches to forage. Among the individuals tracked, only one regularly foraged in a recent cut, but this contained a large number of fallen logs (J.A.T., personal observation). Blackbacked Woodpeckers are known to respond opportunistically to insect outbreaks and forest fires (Bent 1939, Blackford 1955, West and Speirs 1959, Baldwin 1968, Bock and Bock 1974, Murphy and Lehnhausen 1998, Hoyt and Hannon 2002), but our results show that they can also obtain sufficient resources in undisturbed stands with relatively high volumes of dead wood to successfully breed in unburned and non-epidemic landscapes.

\section{Dead-Wood Availability in Home Range}

Pechacek (2004) observed that European Threetoed Woodpeckers adjust home-range size depending on the amount of dead wood available. However, in our study, Black-backed Woodpeckers did not adjust home range size according to the amount of dead wood or dead wood at the early decay stage (mostly available in old coniferous stands). Nevertheless, it was estimated that the home range of breeding Black-backed Woodpeckers contained more than $35 \mathrm{~m}^{3} \bullet \mathrm{ha}^{-1}$ of dead wood, with an average of $42 \%\left(15 \mathrm{~m}^{3} \bullet \mathrm{ha}^{-1}\right)$ being at the early decay stage. This is a relatively large share considering that dead wood is at the early decay stage for a much shorter period of time than the older decay stages (i.e., stages 4 and 5: Vanderwel et al. 2006). Vaillancourt et al. (2008) observed that snags present a dome-shaped distribution across the decay class, with a maximum density occurring in decay class 6 . Other authors have calculated minimum dead-wood values to determine the presence of woodpeckers in the landscape. For example, in Switzerland Bütler et al. (2004) found a 95\% probability of presence of European Three-toed Woodpeckers in forests containing $15 \mathrm{~m}^{3} \cdot \mathrm{ha}^{-1}$ of standing dead wood (snags) over $100 \mathrm{ha}$. In the same study (Bütler et al. 2004), but for Sweden, this figure dropped to $6 \mathrm{~m}^{3} \cdot \mathrm{ha}^{-1}$. In deciduous forests in Poland, White-backed Woodpeckers (Dendrocopus leucotus) were found to require approximately 8 to $17 \mathrm{~m}^{3} \bullet$ ha $^{-1}$ snags over 100 ha (Roberge et al. 2008). 
Fig. 4. Percentage (mean \pm SE) of telemetry locations of foraging Black-backed Woodpeckers (gray bars: $\mathrm{n}=128$ ) and random points (empty bars: $\mathrm{n}=128$ ) falling in a given habitat type.

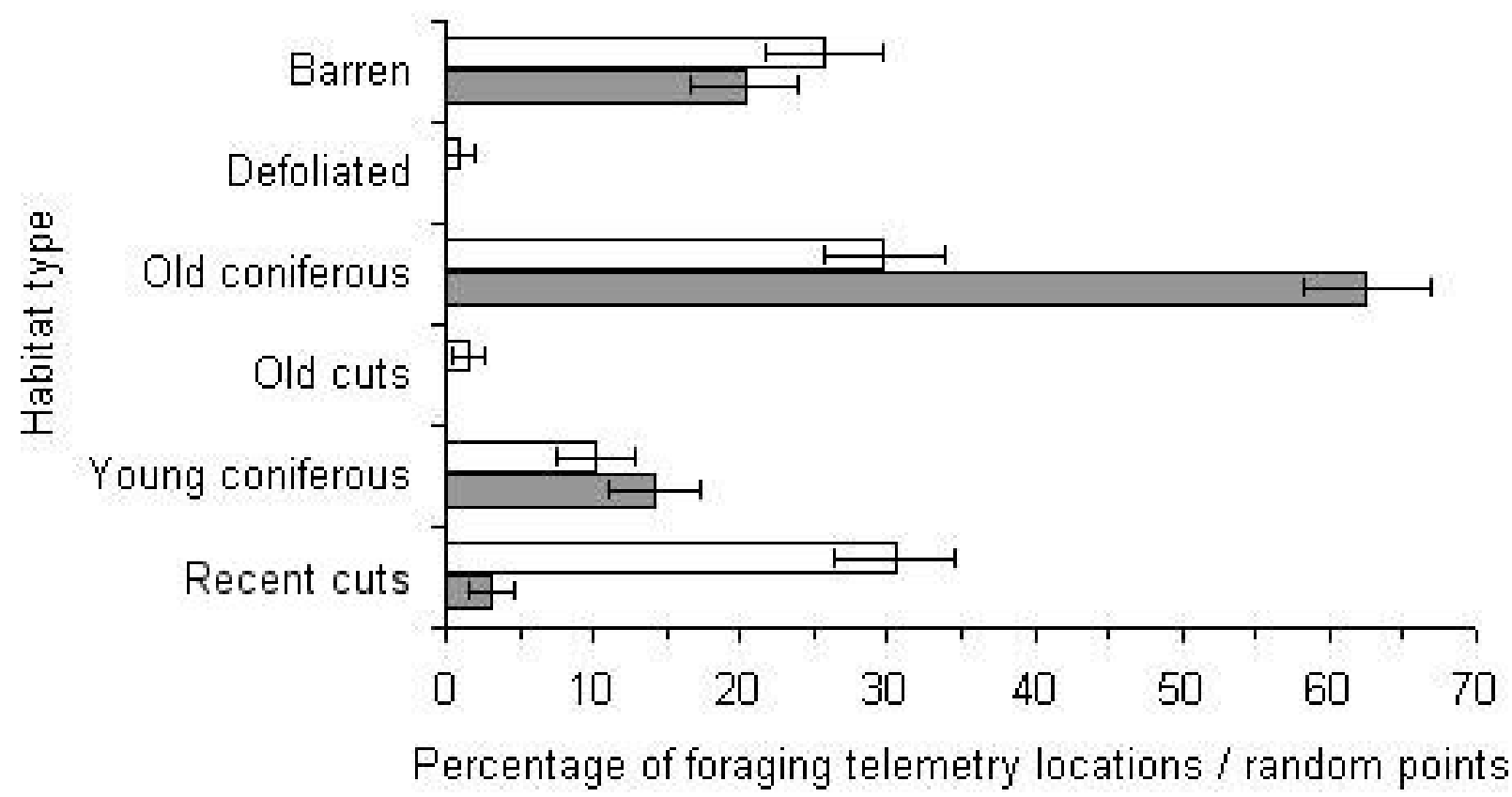

In our study, snags alone represented approximately half the dead-wood volume, so Black-backed Woodpeckers appeared to require a similar volume of standing dead wood as the two abovementioned species. Note that in our study area, Black-backed Woodpeckers were feeding on logs $20 \%$ of the time (Tremblay et al., unpublished data), suggesting that dead logs are important resources in addition to snags. Snag and log volume should be combined to adequately present dead-wood requirements of Black-backed Woodpecker in unburned boreal forest.

No relationship was found between Black-backed Woodpecker home-range size and dead-wood volumes, but this does not mean that the volume of dead wood in the landscape did not affect home range. In fact, that home-range size increased with the median distance between the nearest old coniferous patches. Dead wood is patchily distributed, which is reflected by the high variability around the mean value obtained. Foraging individuals were also observed to repeatedly visit the same dead-wood patches, while showing no interest in other apparently similar patches within their home range (J.A.T., personal observation). It is possible that Black-backed Woodpeckers need a threshold dead-wood volume before they will forage in a given patch. When such suitable foraging patches are abundant in the landscape, home-range size would be expected to be smaller than in landscapes where they are scarce-even though the total dead-wood volume available in the two ranges may be the same. This is supported by the fact that individuals were observed to concentrate their foraging activities at specific sites while flying over apparently "uninteresting stands." At the other extreme, when suitable foraging patches are abundant and close to each other, such as following a recent forest fire, home ranges may be as small as 6.9 ha (A. Nappi, personal communication). A better assessment of food availability for each deadwood decay class would probably provide a more accurate parameter to explain home-range size of this species in unburned forest. However, additional data are required. 
Table 3. Mean (SE) dead wood, snags, and fallen log volumes $\left(\mathrm{m}^{3} \bullet \mathrm{ha}^{-1}\right)$ of total and recently decayed stages (decay classes 1 and 2) by habitat type.

\begin{tabular}{lllllll}
\hline \hline $\begin{array}{l}\text { Habitat type } \\
\text { (no. of plots) }\end{array}$ & \multicolumn{3}{c}{ All decayed stages } & & \multicolumn{2}{l}{ Recent decayed } \\
& Dead wood & Snags & Fallen logs & Dead wood & Snags & Fallen logs \\
\hline Barren (15) & $18.1(4.0)$ & $10.3(2.5)$ & $7.8(2.0)$ & $9.8(2.5)$ & $6.5(2.0)$ & $3.2(1.0)$ \\
Old coniferous (18) & $71.3(11.2)$ & $39.7(9.4)$ & $31.6(3.9)$ & $31.7(5.7)$ & $16.4(3.9)$ & $15.3(2.6)$ \\
Young coniferous (6) & $49.5(14.2)$ & $33.8(11.3)$ & $15.7(5.2)$ & $26.6(8.7)$ & $20.0(6.6)$ & $6.6(1.7)$ \\
Young cut (17) & $29.7(4.4)$ & $2.4(0.6)$ & $27.2(4.3)$ & $8.4(1.1)$ & $0.5(0.2)$ & $7.8(1.1)$ \\
\hline
\end{tabular}

\section{CONCLUSION}

This study was conducted in a landscape shaped by the first phase of a mosaic harvesting approach under which approximately $50 \%$ of the available forest area was harvested, leaving interspersed logged and residual forest blocks. This configuration appears to provide suitable habitat for the two major ecological needs of Black-backed Woodpeckers: foraging and nesting. However, during the second phase of harvesting, the remaining old coniferous stands will be removed as soon as 10 years after the first phase or when the regeneration reaches $3 \mathrm{~m}$ if this height is not reached after 10 years (MRNF 2009). Therefore, in the medium-term, such landscapes are likely to be uninteresting for this species of woodpecker due to a reduction in food availability caused by the removal of old coniferous sites and the reduction of nesting sites caused by the rarity of suitable nesting snags in remnant stands. Even if woodpeckers persist in forest remnants (Imbeau and Desrochers 2002a), we would expect densities and breeding success to decrease.

The results of this study show that Black-backed Woodpeckers can successfully forage and breed in unburned forest that comprises a mix of habitat types, including areas managed under mosaic harvesting regime. Under such conditions, we estimate the required home range for a successful breeding pair of Black-backed Woodpeckers to be approximately 150 ha, of which roughly 56 ha must be old coniferous forest (following Fig. 3). The lowest dead-wood volume found in a home range with successful breeding was $35 \mathrm{~m}^{3} \bullet \mathrm{ha}^{-1}$, where the average of dead wood at the early decay stage was $15 \mathrm{~m}^{3} \cdot \mathrm{ha}^{-1}$ (42\% of the mean dead-wood volume). Although further studies are needed to determine the threshold of dead-wood volume and use relative to prey availability, we suggest that a conservative management approach for Blackbacked Woodpecker should target the above values, where about half of the dead-wood volume consists of standing dead wood. We agree with the suggestion of St.-Laurent et al. (2008) concerning the importance of maintaining blocks of mature closed-canopy forest in managed landscapes until regenerating stands have reached a height that reflects the structural attributes of mature forests, or through an entire logging rotation period. Because of the dependence of Black-backed Woodpeckers on recently dead wood, forest management for this species based on the above target values may be expected to benefit other saproxylic species in the boreal forest. Therefore, as suggested by Goggans et al. (1989) for mature and old-growth lodgepole pine stands in Oregon, we propose the use of Blackbacked Woodpecker as an indicator species, not only in recently burned stands (Hannon and Drapeau 2005), but also in mature and overmature coniferous stands in northeastern North America. 
Table 4. Mean (SE) dead wood, snags, and fallen log volumes $\left(\mathrm{m}^{3} \bullet \mathrm{ha}^{-1}\right)$ of total and recently decayed stages (decay classes 1 and 2) in asymptotic Black-backed Woodpecker home ranges.

\begin{tabular}{lllllll}
\hline \hline Home-range size (ha) & All & \multicolumn{5}{c}{ Recent decay } \\
\hline & Dead wood & Snags & Fallen logs & Dead wood & Snags & Fallen logs \\
100.4 & $35.6(4.1)$ & $18.9(3.8)$ & $16.7(1.5)$ & $20.0(2.8)$ & $14.9(2.9)$ & $5.1(1.9)$ \\
118.5 & $41.7(8.0)$ & $16.7(6.6)$ & $25.0(3.1)$ & $14.2(3.4)$ & $5.1(2.2)$ & $9.1(2.1)$ \\
120.0 & $42.1(4.8)$ & $11.6(4.1)$ & $30.1(4.5)$ & $17.1(5.4)$ & $7.6(4.6)$ & $9.5(1.9)$ \\
132.5 & $61.7(30.1)$ & $35.0(26.3)$ & $26.7(10.8)$ & $22.8(10.9)$ & $11.8(8.4)$ & $11.0(3.1)$ \\
150.9 & $36.4(11.1)$ & $17.3(5.5)$ & $19.2(6.6)$ & $11.8(3.4)$ & $4.2(2.5)$ & $7.6(3.3)$ \\
181.6 & $41.7(14.2)$ & $15.9(7.4)$ & $25.8(7.6)$ & $21.3(10.2)$ & $10.1(5.6)$ & $11.3(4.7)$ \\
256.4 & $37.5(9.7)$ & $23.5(7.4)$ & $14.0(4.0)$ & $18.9(5.9)$ & $12.1(4.8)$ & $6.8(2.3)$ \\
\multirow{2}{*}{ Mean \pm SE } & $42.4(3.2)$ & $19.8(2.7)$ & $22.5(2.1)$ & $18.0(1.4)$ & $9.4(1.4)$ & $8.6(0.8)$ \\
\hline
\end{tabular}

Responses to this article can be read online at: http://www.ace-eco.org/vol4/iss 1/art2/responses/

\section{Acknowledgments:}

This work was supported by the Consortium de Recherche sur la Forêt Boréale (Université du Québec à Chicoutimi; UQAC). We thank AbititiBowater Inc. for their logistical support and $S$. Boily, C. Buidin, P. Desmeules, M. Huot, L. Morin, and Y. Rochepault for their help in the field. Finally, we thank A. Deslauriers and the members of the Laboratoire d'écologie végétale of the UQAC for their helpful comments and A.P. Coughlan and A. M.N. Garside for revising the text. Comments from M.-A. Villard, G. Pasinelli, B. Naef-Daenzer, and an anonymous reviewer greatly helped improve the manuscript. Thanks also to P.-Y. Plourde for providing Figure 1. This study respected the protocols Nos. 0564 and 0668 of the Authorized Animal Care of the UQAC.

\section{LITERATURE CITED}

Backhouse, F. 2005. Woodpeckers of North America. Firefly Books, Buffalo, New York, USA.

Baldwin, P. H. 1968. Predator-prey relationship of birds and spruce beetles. Proceedings North Central Branch, Ecological Society of America 23:90-99.

Bent, A. C. 1939. Life histories of North American woodpeckers. U.S. National Museum Bulletin 174, Washington, D.C., USA.

Bergeron, D., M. Darveau, A. Desrochers, and J.-P. Savard. 1997. Impact de l'abondance des chicots sur les communautés aviaires et la sauvagine des forêts conifériennes et feuillues du Québec méridional. Technical report 271, Environment Canada, Canadian Wildlife Service, Ottawa, Ontario, Canada.

Bergeron, Y., S. Gauthier, V. Kafka, P. Lefort, and D. Lesieur. 2001. Natural fire frequency for the eastern Canadian boreal forest: consequences for sustainable forestry. Canadian Journal of Forest Research 31:384-391.

Bergeron, Y., A. Leduc, B. D. Harvey, and S. 
Gauthier. 2002. Natural fire regime: a guide for sustainable management of the Canadian boreal forest. Sylva Fennica 36:81-95.

Blackford, J. L. 1955. Woodpecker concentration in burned forest. Condor 57:28-30.

Bock, C. E., and J. H. Bock. 1974. On the geographical ecology and evolution of the threetoed woodpeckers, Picoides tridactylus and $P$. arcticus. The American Midland Naturalist 92:397405.

Böhl, J., and U.-B. Brändli. 2007. Deadwood volume assessment in the third Swiss National Forest Inventory: methods and first results. European Journal of Forest Research 126:449-457.

Bull, E. L., S. R. Peterson, and J. W. Thomas. 1986. Resource partitioning among woodpeckers in northeastern Oregon. U.S. Department of Agriculture, Forest Service, Pacific Northwest Research Station. Research Note PNW-444.

Bütler, R., P. Angelstam, P. Ekelund, and R. Schlaepfer. 2004. Dead wood threshold values for the three-toed woodpecker presence in boreal and sub-alpine forest. Biological Conservation 119:305318.

Darveau, M., and A. Desrochers. 2001. Le bois mort et la faune vertébrée: État des connaissances au Québec. Rapport pour le ministère des Ressources naturelles. Université Laval et Centre de recherche en biologie forestière, Quebec City, Quebec, Canada.

Drapeau, P., A. Nappi, M. Saint-Germain, and V.-A. Angers. 2005. Les régimes naturels de perturbations, l'aménagement forestier et le bois mort dans la forêt boréale québécoise. Pages 45-80 in D. Vallauri, J. André, B. Dodelin, R. EynardMachet, and D. Rambaud, editors. Bois mort et à cavités: Une clé pour des forêts vivantes. Lavoisier, Paris, France.

Dudley, J. G., and V. A. Saab. 2007. Home range size of Black-backed Woodpeckers in burned forests of southwestern Idaho. Western North American Naturalist 67:593-600.

Dussault, C., R. Courtois, J. Huot, and J.-P. Ouellet. 2001. The use of forest maps for the description of wildlife habitats: limits and recommendations. Canadian Journal of Forest Research 31:1227-1234.

Environmental Systems Research Institute (ESRI). 1996. ArcView GIS and spatial analyst. ESRI, Inc. Redlands, California, USA.

Girardin, M.P., M.D. Flannigan, J.C. Tardif, and Y. Bergeron. 2008. Climatologie, métérologie et feux de forêts. Pages 83-107 in S. Gauthier, M.-A. Vaillancourt, A. Leduc, L. De Grandpré, D. Kneeshaw, H. Morin, P. Drapeau, and Y. Bergeron, editors. Aménagement écosystique en forêt boréale. Presses de l'Université du Québec, Quebec City, Quebec, Canada.

Goggans, R., R. D. Dixon, and L. C. Seminara. 1989. Habitat use by three-toed and Black-backed Woodpeckers. Technical Report 87-3-02. USDA Deschutes National Forest, Bend, Oregon, USA.

Hannon, S.J., and P. Drapeau. 2005. Bird responses to burning and logging in the boreal forest of Canada. Studies in Avian Biology 30:97-115.

Harmon, M. E., and J. Sexton. 1996. Guidelines for measurements of woody detritus in forest ecosystems. LTER Network Publication No. 20. University of Washington, Seattle, Washington, USA.

Hayne, D. W. 1949. Calculation of size of homerange. Journal of Mammalogy 30:1-18.

Hoyt, J. S., and S. J. Hannon. 2002 Habitat associations of black-backed and three-toed woodpeckers in the boreal forest of Alberta. Canadian Journal of Forest Research 32:18811888.

Hutto, R. L. 1995. Composition of bird communities following stand replacement in northern Rocky Mountain (USA) conifer forests. Conservation Biology 9:1041-1058.

Ibarzabal, J., and P. Desmeules. 2006. Blackbacked Woodpecker (Picoides arcticus) detectability in unburned and recently burned mature forests in north-eastern North America. Annales Zoologica Fennici 43:228-234.

Imbeau, L., and A. Desrochers. 2002a. Area sensitivity and edge avoidance: the case of the Three-toed Woodpecker (Picoides tridactylus) in a 
managed forest. Forest Ecology and Management 164:249-256.

Imbeau, L., and A. Desrochers. 2002b. Foraging ecology and use of drumming trees by three-toed woodpeckers. Journal of Wildlife Management 66:222-231.

Imbeau,L., J.-P. L. Savard, and R. Gagnon. 1999. Comparing bird assemblages in successional black spruce stands originating from fire and logging. Canadian Journal of Zoology 77:1850-1860.

Johnson, D. H. 1980. The comparison of usage and availability measurements for evaluating resource preference. Ecology 61:65-71.

Kenward, R. E. 2001. A manual for wildlife radio tagging. Revised edition. Academic Press, London, UK.

Kenward, R., A. South, and S. Walls. 2003. Range V1.2: for the analysis of tracking and location data. Anatrack Ltd., Wareham, UK.

Koivula, M. J., and F. K. A. Schmiegelow. 2007. Boreal woodpecker assemblages in recently burned forested landscapes in Alberta, Canada: effects of post-fire harvesting and burn severity. Forest Ecology and Management 242:606-618.

Liu, H., and T. Wu. 2003. Estimating the area under a receiver operating characteristic curve for repeated measures design. Journal of Statistical Software 8(12).

Manel, S., H. C. Williams, and S. J. Ormerod. 2001. Evaluating presence-absence models in ecology: the need to account for prevalence. Journal of Applied Ecology 38:921-931.

Martin, K., K. E. H. Aitken, and K. L. Wiebe. 2004. Nest sites and nest webs for cavity-nesting communities in interior British Columbia, Canada: Nest characteristics and niche partitioning. Condor 106:5-19.

Martin, K., and J. M. Eadie. 1999. Nest webs: a community-wide approach to the management and conservation of cavity-nesting forest birds. Forest Ecology and Management 115:243-257.

McGarigal, K., S. A. Cushman, M. C. Neel, and E. Ene. 2002. FRAGSTATS: spatial pattern analysis program for categorical maps. Computer software program produced by the authors at the University of Massachusetts, Amherst, Massachusetts, USA. [online] URL: http://www.umass.edu/landeco/ research/fragstats/fragstats.html.

McRae, D. J., L. C. Duchesne, B. Freedman, T. J. Lynham, and S. Woodley. 2001. Comparisons between wildfire and forest harvesting and their implications in forest management. Environmental Reviews 9:223-260.

Mech, L. D. 1983. Handbook of animal radiotracking. University of Minneapolis Press, Minneapolis, Minnesota, USA.

Ministère des Ressources Naturelles et de la Faune du Québec (MRNF). 2009. Règlement sur les normes d'intervention dans les forêts du domaine de l'état. éditeur officiel du Québec, Quebec City, Quebec, Canada. [online] URL: http://www.canlii. org/fr/qc/legis/regl/rq-c-f-4.1-r1.001.1/derniere/.

Murphy, E. C., and W. A. Lehnhausen. 1998. Density and foraging ecology of woodpeckers following a stand-replacement fire. Journal of Wildlife Management 62:1359-1372.

Nappi, A., and P. Drapeau. 2009. Reproductive success of the black-backed woodpecker (Picoides arcticus) in burned boreal forests: are burns source habitats? Biological Conservation, in press. doi: 10.1016/j.biocon.2009.01.022.

Nappi, A., P. Drapeau, J.-F. Giroux, and J.-P. Savard. 2003. Snag use by foraging Black-backed Woodpeckers (Picoides arcticus) in a recently burned eastern boreal forest. Auk 120:505-511.

Pasinelli, G. 2000. Oaks (Quercus sp.) and only oaks? Relations between habitat structure and home range size of the middle spotted woodpecker (Dendrocopos medius). Biological Conservation 93:227-235.

Pechacek, P. 2004. Spacing behaviour of Eurasian Three-toed Woodpecker (Picoides tridactylus) during the breeding season in Germany. Auk 121:58-67.

Pechacek, P., and W. d'Oleire-Oltmanns. 2004. Habitat use of the three-toed woodpecker in central Europe during the breeding period. Biological Conservation 116:333-341. 
Potvin, F., L. Bélanger, and K. Lowell. 1999. Validité de la carte écoforestière pour décrire les habitats fauniques à l'échelle locale : une étude de cas en Abitibi-Témiscamingue. The Forestry Chronicle 75:851-859.

Powell, H. 2000. The influence of prey density on post-fire habitat use of the Black-backed Woodpecker. Thesis, University of Montana, Missoula, Montana, USA.

Raphael, M. G., and M. White. 1984. Use of snags by cavity-nesting birds in the Sierra Nevada. Wildlife Monographs 86:1-66.

Roberge, J.-M., P. Angelstam, and M.-A. Villard. 2008. Specialised woodpeckers and naturalness in hemiboreal forests - deriving quantitative targets for conservation planning. Biological Conservation 141:997-1012.

Saab, V., R. Brannon, J. Dudley, L. Donohoo, D. Vanderzanden, V. Johnson, and H. Lachowski. 2002. Selection of fire-created snags at two spatial scales by cavity nesting birds. Pages $835-848$ in $\mathrm{P}$. J. Shea, W. F. Laudenslayer, Jr., B. Valentine, C. P. Weatherspoon, and T. E. Lisle, editors. Proceedings of the Symposium on the Ecology and Management of Dead Wood in Western Forests, 2-4 November 1999. Technical Report PSWGTR-181. USDA Forest Service, Reno, Nevada, USA.

Saab, V. A., and J. G. Dudley. 1998. Responses of cavity-nesting birds to stand-replacement fire and salvage logging in ponderosa pine/Douglas-fir forests of southwestern Idaho. Research Paper RMRS-RP-11. USDA Forest Service, Rocky Mountain Research Station, Moscow, Idaho, USA.

Saab, V.A., R. E. Russell, and J. G. Dudley. 2007. Nesting densities of cavity-nesting birds in relation to postfire salvage logging and time since wildfire. Condor 109:97-108.

SAS Institute. 2008. SAS OnlineDoc Version 9.1. SAS Institute, Cary, North Carolina, USA. [online] URL: http://support.sas.com/documentation/ onlinedoc/91pdf/index.html.

Saucier, J. P., J. F. Bergeron, P. Grondin, and A. Robitaille. 1998. Les zones de végétation et les domaines bioclimatiques du Québec. Ministère des Ressources naturelles du Québec, Forêts Québec, Sainte-Foy, Quebec, Canada.
Seaman, D. E., J. J. Millspaugh, B. J. Kernohan, G. C. Brundige, K. J. Raedeke, and R. A. Gitzen. 1999. Effects of sample size on kernel home range estimates. Journal of Wildlife Management 63:739_ 747.

Setterington, M. A., I. D. Thompson, and W. A. Montevecchi. 2000. Woodpecker abundance and habitat use in mature balsam fir forests in Newfoundland. Journal of Wildlife Management 64:335-345.

Shapiro, S. S., and M. B. Wilk. 1965. An analysis of variance test for normality (complete samples). Biometrika 52:591-611.

Short, L. L. 1974. Habits and interactions of North American Three-toed Woodpeckers (Picoides arcticus and Picoides tridactylus). American Museum Novitates 2547:1-42.

St.-Laurent, M.-H., J. Ferron, S. Haché, and R. Gagnon. 2008. Planning timber harvest of residual forest stands without compromising bird and small mammal communities in boreal landscapes. Forest Ecology and Management 254:261-275.

Thompson, I. D., H. A. Hogan, and W. A. Montevecchi. 1999. Avian communities of mature balsam fir forests in Newfoundland: age-dependant and implications for timber harvesting. Condor 101:311-323.

Tyrrell, L. E., and T. R. Crow. 1994. Structural characteristics of old-growth hemlock-hardwood forests in relation to age. Ecology 75:370-386.

Vaillancourt, M.-A., P. Drapeau, S. Gauthier, and M. Robert. 2008. Availability of standing trees for large cavity-nesting birds in the eastern boreal forest of Québec, Canada. Forest Ecology and Management 255:2272-2285.

Vanderwel, M. C., J. R. Malcolm, S. M. Smith, and N. Islam. 2006. Insect community composition and trophic guild structure in decaying logs from eastern Canadian pine-dominated forests. Forest Ecology and Management 225:190-199.

Villard, P. 1994. Foraging behaviour of Blackbacked and Three-toed Woodpeckers during spring and summer in a Canadian boreal forest. Canadian Journal of Zoology 72:1957-1959. 
Villard, P., and C. W. Beninger. 1993. Foraging behavior of male black-backed and hairy woodpeckers in a forest burn. Journal of Field Ornithology 64:71-76.

Virkkala, R. 1987. Effects of forest management on birds breeding in northern Finland. Annales Zoologi Fennici 24:281-294.

West, J. D., and J. M. Speirs. 1959. The 19561957 invasion of three-toed woodpeckers. Wilson Bulletin 71:348-371.

White, G. C., and R. A. Garrott. 1990. Analysis of wildlife radio-tracking data. Academic Press, London, UK.

Worton, B. J. 1989. Kernel methods for estimating the utilization distribution in home-range studies. Ecology 70:164-168.

Zweig, M. H., and G. Campbell. 1993. Receiveroperating characteristic (ROC) plots: a fundamental evaluation tool in clinical medicine. Clinical Chemistry 39:561-577. 